\title{
CORRESPONDENCE
}

\section{A history of the Falkland Islands}

SIR - In your leading article referring to the Falkland Islands conflict (see Nature 8 April, p.480), it is stated that the only claim of Argentina to the ownership of the islands is the proximity to the Argentine coast. Since we consider this statement to be in error we give here a detailed account of the historical events and the cause of the present conflict.

The discovery: The strongest evidence available indicates that the discovery of the islands can be attributed to the crew of the ship "San Anton", a member of the Spanish expedition led by Hernando de Magallanes (Magellan). With the name of "Islas de Sanson" (an abbreviation and slight modification of the ship's name) the islands are depicted in several Spanish maps from 1522 to 1590 , as well as in the Italian map of Agnese, of 1536, where the Magellan route is indicated.

Naturally, Spanish dominion over the islands was proclaimed (in accordance with Papal bulls and treaties with Portugal) and in 1580 a garrison was settled near the Magellan Strait having jurisdiction over the mainland and the nearby islands.

In 1619 , on a map made under the direction of the Dutch sailor Sebald de Weert, the islands appear with the name of "Sebaldin islands". The first British descriptions were published in 1622 but even British scholars are doubtful about these reports.

However, the British sea rover William Dampier was there by 1648 and in 1690 John Strong gave the name "Falkland Sound" to the strait between the two main islands, a name that in the English literature was later extended to the whole archipelago.

The occupation: The islands were first occupied in 1764 by the Frenchman Louis Antoine de Bougainville who established a small colony in a place he named Port Louis. Since most settlers were from the French port of St Malo the islands took the name of "Iles des Malouines", which in the Spanish literature became "Islas Malvinas".

Once Spain realized that the French had settled there the Crown made the appropriate claims to France and in 1767 the French left. A small Spanish garrison subsequently remained in Port Louis, which took the name of "Puerto Soledad".

In the meantime (1765) a small group of people from Britain had settled in a place which they called Port Egmont. Once again, Spain made the respective claims and since the British did not want to leave peacefully they were expelled by force in 1770 . The diplomatic conflict that started ended by an agreement between Britain and Spain in which the British were reinstalled in Port Egmont in 1771 and left "spontaneously" in 1774. The British occupation lasted four years in all.

In 1811, after 44 years of regular occupation, the Spanish garrison was sent to Montevideo because of the War of Independence that had started in Buenos Aires in 1810. This war led to the Declaration of Independence in 1816, following the North American example.

Argentina, as heir to the Spanish possessions, took charge of the Islas Malvinas in 1820 and left a representative of the Government of Buenos Aires.

In 1825 Britain recognized the independence of Argentina and signed a treaty of peace and commerce without questioning the Argentine possession over the islands.

In 1829 the administration of the island was reorganized and a governor was sent from Buenos Aires. He settled there with his family.

On 2 January 1833 John James Onslow, commanding the British frigate "Clio", dismissed the Argentine authorities by force. The British forces stayed there until 2 April 1982.

The claims: The Argentine government considered the British action to be plunder and immediately made the corresponding claim. Since then this claim has been repeated by the Argentine government (regardless of its political affiliation) at every convenient opportunity but no satisfactory answer has been obtained.

The creation of the United Nations opened a new possibility, particularly when in 1960 it decided to end colonialism. Britain spontaneously presented the "Falkland Islands" as a "non-autonomous territory", an expression that replaced the old term

"colony" (Resolution No. 1514, XV General Assembly).

Since Argentina claimed the property of the islands, in 1965, after patient diplomatic procedures, the 20th General Assembly issued Resolution No. 2065 (approved by 94 votes in favour, none against and 14 abstentions, Britain among them) in which both Britain and Argentina were invited to solve the conflict in a peaceful way.

Conversations started and during this time Argentina has steadily contributed to the improvement of the living conditions of the islanders which were neglected by the British government. Schools were improved, an airport was built (the only one in the islands) and twice-weekly air communication with the continent through an Argentine airline was started, thus ending the island's long isolation. Free health assistance and education on the continent were also offered to the islanders. It is important to stress that the islanders were primarily dependent on the "Falkland Islands Company" which controlled every aspect of their lives: production, commerce and even food supply. The company also owns most of the useful land.

At first Britain seemed to accept a diplomatic solution and even stated that she would transfer the islands to Argentina provided the interest of the 1,800 inhabitants was taken into consideration. However, Britain subsequently paid no further attention to the subject and no more steps were made in the negotiation.

The conflict: The present conflict originated as follows: At Grytviken, San Pedro Island, a Malvinas Islands dependence, there was on old and abandoned whaling factory. An Argentine scrap dealer made the proper arrangements with the owner of the factory to dismantle it and sell it for scrap. The arrangements were made according to British law and with the British authorities' approval. Nevertheless, once the Argentine workers were at Grytviken, they were considered to be "invaders" and a warship was sent to clear them out. Argentina in turn first sent another warship to protect the workers and then occupied the islands. The recovery of the whole archipelago was made without any harm to the British. Not a single drop of British blood was shed but four Argentine people lost their lives.

Alberto C. TAQuinI

Asociacion Argentina Para el

Progreso de las Ciencias,

Buenos Aires, Argentina

\section{Logarithmic SI}

SIR - I have for some time made private use of a notation for expressing numbers and measurements that others might perhaps also find useful. It was suggested to me by the symbol " $p \mathrm{H}$ ".

The first step is to let the prefix $p$ mean "antilog to the base 10". So p0 is 1, p6 is $1,000,000 ; 2,000$ is $2 \mathrm{p} 3$ or, to one decimal place, p3.3. For, say, 0.02 there is a choice of $\overline{\mathrm{p}} 2.3, \overline{\mathrm{p}} 1.7$ or $2 \overline{\mathrm{p}} 2$. (More generally, $\mathrm{p}$ may be regarded as $p^{1}$, giving $p^{0} 2$ as $2, p^{1} 2$ as 100 , $p^{2} 2$ as $p 100$, and so on - so $p^{9} 9$ is a very large number.)

The next step is to let $\mathrm{pQ} 0$ mean the SI unit value of some quantity $Q$; this generates a notation that is particularly useful for very large or very small measurements.

My own practice is to use $\mathrm{pLO}, \mathrm{pM} 0$ and pT0 for $1 \mathrm{~m}, 1 \mathrm{~kg}$ and $1 \mathrm{~s}$ respectively. Area, volume, speed and acceleration may conveniently be written $\mathrm{pL}^{2}, \mathrm{pL}^{3}, \mathrm{pL}^{*}$ and $\mathrm{pL}^{* *}$ (I say 'pL stars' - c.f. $\mathrm{x}$ ); the two latter $\mathrm{pL} / \mathrm{T}$ and $\mathrm{pL} / \mathrm{T}^{2}$ alternatively. For other units I use the SI symbol itself -1 joule is pJo. ( I also write $\mathrm{pD} 0$ for $1 \mathrm{~kg} \mathrm{~m}^{-2}$.)

As examples, electron mass and radius $\left(m_{e}\right.$ and $r_{e}$ ) are $\overline{\mathrm{p}} \mathrm{M} 30.0$ and $\overline{\mathrm{p}} \mathrm{L} 14.6$; the solar mass pM30.3 and the Solar System's diameter about pL13; the speed of light $\bar{p} L * 8.5$ and of continental drift about $\mathrm{pL} * 9$; and a year is within 1 part in 500 of pT71/2.

This notation is particularly practical in that it avoids the awkwardness of the half-sized superscript $\left(2 \times 10^{30} \mathrm{~kg}\right)$, while getting round the somewhat clumsy SI prefix system, which in general usage has caught on only rather patchily.

London W5, UK

J. A. NicOll

\section{Support the Zoo}

SIR - The article by Jane Wynn in Nature 13 May (p.97) points up what seems to me to be an obvious anomaly. Kew Gardens is (rightly) given enough Exchequer support to enable it to charge an entry fee of $10 \mathrm{p}$, and to have over 1 million visitors a year. London Zoo, which has similar functions, is forced to try to charge an "economic" entrance fee and hence price itself out of existence. Why the difference?

J. R. BAKER

The Institute of Terrestrial Ecology,

Cambridge, UK 